\title{
Distribution of proteins labelled during meiotic maturation in rabbit and pig eggs at fertilization
}

\author{
J. Motlík, V. Kopečný, J. Pivko* and J. Fulka \\ Czechoslovak Academy of Sciences, Institute of Animal Physiology and Genetics, Department of \\ Genetics, 27721 Liběchov, Czechoslovakia, and *Institute of Animal Production, 94992 Nitra, \\ Czechoslovakia
}

\begin{abstract}
Summary. The fate of proteins formed during meiotic maturation was examined after fertilization. Rabbit ovarian oocytes were labelled in vitro with $\left[{ }^{3} \mathrm{H}\right]$ lysine and fertilized after transfer to recipients. A significant accumulation of the label was detected autoradiographically only in fully grown male and female pronuclei.

Pig oocytes at the germinal vesicle and metaphase I stages were labelled with $\left[{ }^{3} \mathrm{H}\right]$ lysine, $\left[{ }^{3} \mathrm{H}\right]$ methionine or $\left[{ }^{3} \mathrm{H}\right]$ tryptophan and fertilized. Pronuclei were labelled by all 3 precursors. During cleavage, eggs labelled with $\left[{ }^{3} \mathrm{H}\right]$ lysine lost the nuclear label by the 4-cell stage. However the $\left[{ }^{3} \mathrm{H}\right]$ methionine label was present in the cytoplasm and marked in the nuclei at the 4-cell stage, while the $\left[{ }^{3} \mathrm{H}\right]$ tryptophan label was still clear in 8-cell embryos.
\end{abstract}

\section{Introduction}

A conspicuous feature of mammalian oocyte metabolism during the period of the meiotic maturation is a very high accumulation of newly synthesized proteins in the germinal vesicle (Wassarman \& Letourneau, 1976; Motlik, Kopečný \& Pivko, 1978) as well as specific changes in the pattern of protein synthesis (Schultz \& Wassarman, 1977; Van Blerkom \& McGaughey, 1978a). It has been suggested that this immense protein accumulation in the germinal vesicle may serve as a store for embryonic development and probably also as a mechanism for cytoplasmic control of nuclear function (reviewed by Wassarman \& Letourneau, 1976).

The present work was consequently undertaken to study the possible participation of proteins synthesized during meiotic maturation in pronuclear formation and growth. Proteins labelled by $\left[{ }^{3} \mathrm{H}\right]$ lysine (see Wassarman \& Letourneau, 1976), $\left[{ }^{3} \mathrm{H}\right]$ methionine and $\left[{ }^{3} \mathrm{H}\right]$ tryptophan (Hoffner \& Di Berardino, 1977; De Robertis, Longthorne \& Gurdon, 1978) were studied by autoradiography.

\section{Materials and Methods}

Oocyte source, culture, pre-labelling and fertilization

Rabbit. Sexually mature does were injected on the 16th, 17th and 18th days of pseudopregnancy with 15 i.u. FSH (Folicotropin: Spofa). Oocytes with cumulus cells from the preovulatory follicles were obtained on the 19th day of pseudopregnancy after FSH treatment only or 3 or $5-8 \mathrm{~h}$ after administration of 100 i.u. hCG (Praedyn: Spofa). Oocytes were immediately transferred into a drop of culture medium (Motlik \& Fulka, 1974b) or into medium enriched by $\left[{ }^{3} \mathrm{H}\right]$ lysine (L- $\left[4,3-{ }^{3} \mathrm{H}\right]$ lysine monohydrochloride, sp. act. $250 \mathrm{mCi} / \mathrm{mmol}$ : Radiochemical 
Centre, Amersham, U.K.) in a concentration of $100 \mu \mathrm{Ci} / \mathrm{ml}$. After $3 \mathrm{~h}$ of pre-labelling in the tritiated medium the oocytes were washed 3 times in an unlabelled medium and cultured in unlabelled medium for 2-7 h (see Table 1).

At the end of the culture period the oocytes were transferred into the oviducts of does injected with 100 i.u. hCG and mated $12 \mathrm{~h}$ earlier. After 5 or $8 \mathrm{~h}$ the oocytes were flushed from

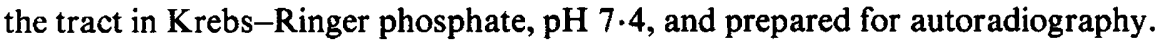

Pig. The gilts of the miniature pigs (crosses of the Minnesota and Göttingen strains) were hormonally stimulated on the 16th day of the cycle with 500 i.u. PMSG (Antex: Leo, Copenhagen). After 72-80 h, 500 i.u. hCG (Praedyn: Spofa) were injected. At 8 or $24 \mathrm{~h}$ after the hCG injection, all gilts were mated twice before unilateral ovariectomy. Oocytes with cumulus cells were obtained from preovulatory follicles in the excised ovary and were washed and placed in culture medium (Motlik \& Fulka, 1974a) enriched by the radioactive precursors (all from the Radiochemical Centre, Amersham, U.K.) $\left[{ }^{3} \mathrm{H}\right]$ lysine (L- $\left[4,5-{ }^{3} \mathrm{H}\right]$ lysine monohydrochloride, $\mathrm{sp}$. act. $250 \mathrm{mCi} / \mathrm{mmol}),\left[{ }^{3} \mathrm{H}\right]$ methionine $\left(\mathrm{L}\left[2(\mathrm{n})-{ }^{3} \mathrm{H}\right]\right.$ methionine, sp. act. $\left.8 \mathrm{Ci} / \mathrm{mmol}\right)$ or $\left[{ }^{3} \mathrm{H}\right]$ tryptophan (L-[5(n)- $\left.{ }^{3} \mathrm{H}\right]$ tryptophan, sp. act. $23 \mathrm{Ci} / \mathrm{mmol}$ ) at a final concentration 100 $\mu \mathrm{Ci} / \mathrm{ml}$. After $3 \mathrm{~h}$ culture in the tritiated medium the oocytes were washed 3 times in an unlabelled medium and subsequently cultured in unlabelled medium for 10 or $24 \mathrm{~h}$ (see Table 2). Cultured oocytes were returned to the ampullae of the oviducts associated with the excised ovaries. The gilts were killed 16,24 or $48 \mathrm{~h}$ after transfer, eggs were flushed out with KrebsRinger phosphate, $\mathrm{pH} 7.4$, and prepared for autoradiography. Eggs obtained from the contralateral side served as controls for the developmental stage.

\section{Cytological procedures}

The oocytes were prepared for autoradiography as semithin Durcupan (Fluka) sections or as air-dried spreads. For sections, the oocytes were fixed with $2 \%$ glutaraldehyde in PBS and postfixed with 1\% osmium tetroxide in PBS (Szöllösi \& Hunter, 1973), embedded in Durcupan (Fluka) and cut to about $0 \cdot 1-0.5 \mu \mathrm{m}$ thick sections. For air-dried spreads the zona pellucida was dissolved by $0.25 \%$ pronase and the oocytes were maintained in a protein-rich medium for a further $10 \mathrm{~min}$ and then transferred onto slides. The slides were air-dried, fixed in phosphatebuffered formalin at $4{ }^{\circ} \mathrm{C}$ overnight, washed with running tap water, extracted with $5 \%$ ice-cold trichloracetic acid for $5 \mathrm{~min}$, washed again with running tap water, rinsed with $70 \%$ alcohol and

\section{PLATE 1}

Figs 1-3. The $\left[{ }^{3} \mathrm{H}\right]$ lysine-labelled proteins synthesized during meiotic maturation of rabbit oocytes are concentrated markedly in the newly forming pronuclei: male and female pronuclear labelling in an air-dried spread preparation (Fig. 1); both pronuclei shown in conjugation in a section (Fig. 2); label accumulation in a parthenogenetically activated egg (Fig. 3). $\times 800$.

Figs 4 and 5. Pronuclei in syngamy in pig eggs prelabelled during meiotic maturation with $\left[{ }^{3} \mathrm{H}\right]$ methionine and $\left[{ }^{3} \mathrm{H}\right]$ tryptophan show considerable accumulation of the label in comparison to cytoplasm. Fig. 4. Three pronuclei labelled by $\left[{ }^{3} \mathrm{H}\right]$ methionine (probably a polyspermic egg). $\times 400$. Fig. 5. Pronuclei at syngamy labelled with $\left[{ }^{3} \mathrm{H}\right]$ tryptophan. $\times 250$.

Fig. 6. Blastomere of a pig 4-cell egg prelabelled at metaphase I with $\left[{ }^{3} \mathrm{H}\right]$ lysine. The nucleus of the blastomere and the surrounding cytoplasm carry similar intensity of labelling. $\times 600$.

Fig. 7. A 3-cell pig egg showing that $\left[{ }^{3} \mathrm{H}\right]$ methionine-labelled proteins are still being accumulated in the nuclei. $\times 300$.

Fig. 8. An 8-cell pig egg labelled with $\left[{ }^{3} \mathrm{H}\right]$ tryptophan showing that selective transport of this label to the nuclei (arrowed) is still active. $\times 300$. 

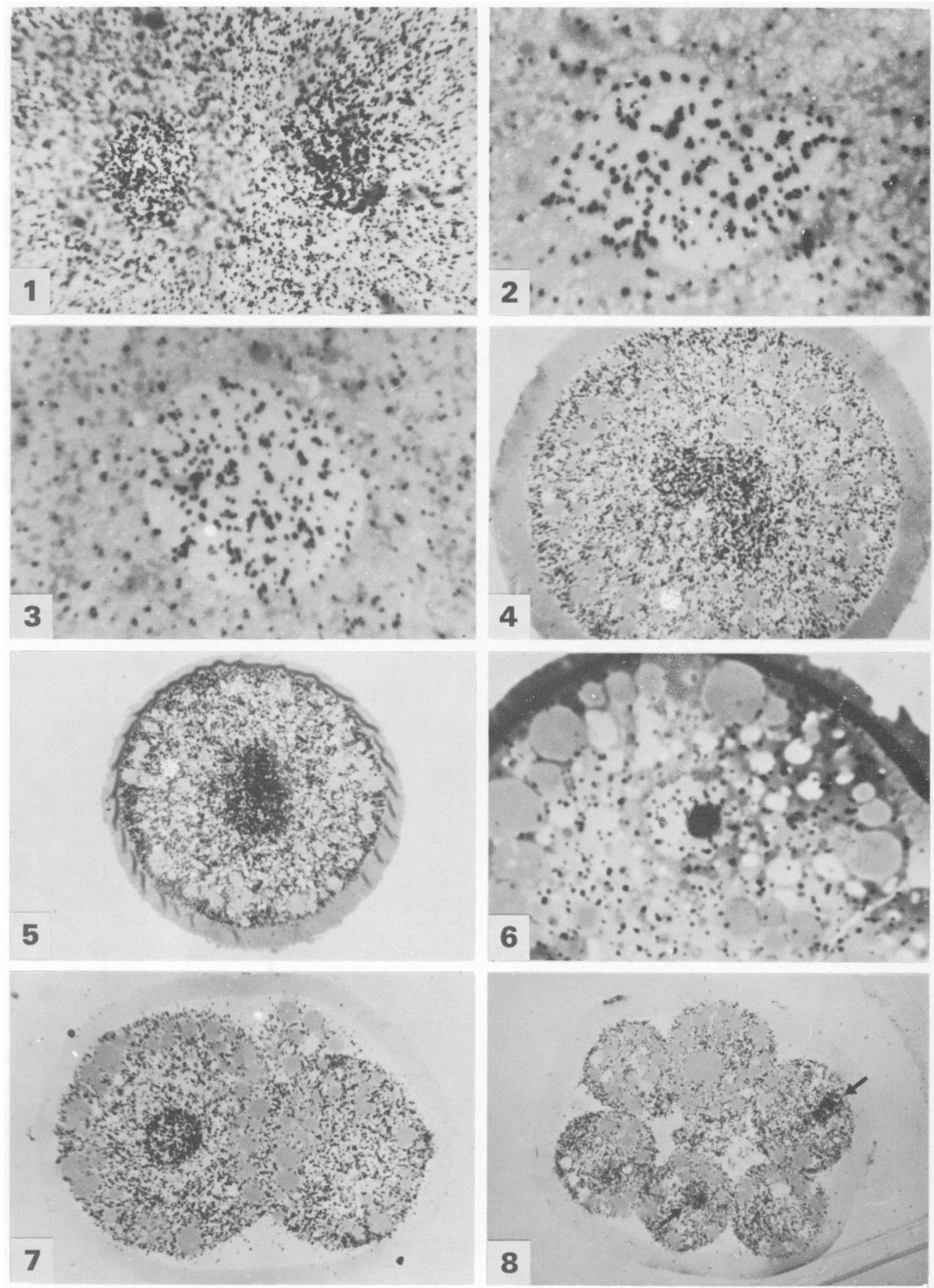
air-dried. All slides were coated with nuclear liquid emulsion Ilford K.5, exposed in evacuated containers for 30 days and developed with D.19b. The stain was toluidine blue at $\mathrm{pH} 4.2$ or methylene blue (sections) after development.

\section{Results}

\section{Rabbits (Table 1)}

The ooplasm of all the ova exposed only to FSH was labelled and labelling of both pronuclei, either fully developed (Pl. 1, Fig. 1) or already in syngamy (Pl. 1, Fig. 2), was detected. Only 1 labelled pronucleus was detected in 3 oocytes and 3 labelled pronuclei were found in 1 oocyte. Conspicuous labelling was also seen in polar bodies in the perivitelline space. When the oocytes were obtained $3 \mathrm{~h}$ after hCG, labelled pronuclei were again detected in air-dried spreads and sections. Only one pronucleus was identified in 3 oocytes (Pl. 1, Fig. 3). These pronuclei were probably the result of parthenogenetic activation because no sperm structures were detected. These results are interpreted as a visualization of the accumulation of $\left[{ }^{3} \mathrm{H}\right]$ lysine-labelled proteins, synthesized during meiotic maturation, in both pronuclei after fertilization.

Oocytes labelled 5-8 $\mathrm{h}$ after the hCG injection were recovered $5 \mathrm{~h}$ after transfer to study earlier stages of pronuclear development. However, the label in the early stages of pronuclear development could not be distinguished from that of the surrounding ooplasm (Table 1).

Table 1. Fate of $\left[{ }^{3} \mathrm{H}\right]$ lysine labelled proteins of rabbit oocytes after fertilization

\begin{tabular}{|c|c|c|c|c|c|c|c|c|c|c|}
\hline \multicolumn{4}{|c|}{ Intervals (h) } & & & \multicolumn{5}{|c|}{ Labelled oocytes* } \\
\hline \multirow{2}{*}{$\begin{array}{c}\mathrm{hCG}- \\
\text { ovariectomy }\end{array}$} & \multirow{2}{*}{$\begin{array}{c}\text { Culture } \\
\text { with } \\
{\left[{ }^{3} \mathrm{H}\right] \text { lysine }}\end{array}$} & \multirow{2}{*}{$\begin{array}{l}\text { Further } \\
\text { culture }\end{array}$} & \multirow{2}{*}{$\begin{array}{c}\text { In } \\
\text { oviduct }\end{array}$} & \multicolumn{2}{|c|}{ No. of oocytes } & \multicolumn{4}{|c|}{ Pronuclei } & \multirow[b]{2}{*}{ Syngamy } \\
\hline & & & & Evaluated & Fertilized & Early & 1 & 2 & 3 & \\
\hline \multicolumn{11}{|c|}{ Air-dried preparations } \\
\hline 0 & 3 & 7 & $8-10$ & 40 & 12 & & 3 & 6 & 1 & 2 \\
\hline 3 & 3 & 4 & 10 & 42 & 8 & & & & & 8 \\
\hline $5-8$ & 3 & 2 & 5 & 30 & 9 & (8) & & 1 & & \\
\hline \multicolumn{11}{|l|}{ Sections } \\
\hline 0 & 3 & 7 & 10 & 30 & 8 & & 3 & 3 & & 2 \\
\hline 3 & 3 & 4 & 10 & 35 & 15 & & 3 & $4(2)$ & & 6 \\
\hline
\end{tabular}

* The pronuclei were labelled more intensely than the cytoplasm except in those embryos indicated in parentheses for which the pronuclear label was similar to or less than that in the cytoplasm.

\section{Pigs (Table 2)}

The cytoplasm of oocytes obtained $16 \mathrm{~h}$ after transfer to the oviduct was intensely labelled when $\left[{ }^{3} \mathrm{H}\right]$ methionine and $\left[{ }^{3} \mathrm{H}\right]$ tryptophan were used but less so with $\left[{ }^{3} \mathrm{H}\right]$ lysine. With all 3 precursors, the pronuclei in syngamy were more intensely labelled than the cytoplasm (Pl. 1, Fig. 5). Three pronuclei of a polyspermic oocyte were labelled by $\left[{ }^{3} \mathrm{H}\right]$ methionine (Pl. 1, Fig. 4). These results indicate that the proteins that have been labelled in the germinal vesicle stage accumulate in the pronuclei.

Oocytes obtained for labelling $24 \mathrm{~h}$ after hCG were in metaphase I. The accumulation of $\left[{ }^{3} \mathrm{H}\right]$ lysine-labelled proteins in nuclei of 2-cell embryos was only slight and nuclei of 4-cell embryos were labelled equally with the surrounding cytoplasm (Pl. 1, Fig. 6). However, the nuclei of 2- and 4-cell embryos and 2-, 4- and 8-cell embryos showed intense accumulation of $\left[{ }^{3} \mathrm{H}\right]$ methionine (Pl. 1, Fig. 7) and $\left[{ }^{3} \mathrm{H}\right]$ tryptophan (Pl. 1, Fig. 8), respectively. Therefore, though the selective transport of $\left[{ }^{3} \mathrm{H}\right]$ lysine-labelled proteins from the cytoplasm to the nuclei of cleaved embryos ceases, the accumulation of proteins labelled with $\left[{ }^{3} \mathrm{H}\right]$ methionine and $\left[{ }^{3} \mathrm{H}\right]$ tryptophan continues at least up to the 4- and 8-cell stages, respectively. 
Table 2. Fate of $\left[{ }^{3} \mathrm{H}\right]$ lysine-, $\left[{ }^{3} \mathrm{H}\right]$ methionine- and $\left[{ }^{3} \mathrm{H}\right]$ tryptophan-labelled proteins in pig oocytes after fertilization

\begin{tabular}{|c|c|c|c|c|c|c|c|c|c|}
\hline \multicolumn{4}{|c|}{ Intervals (h) } & & & & & & \\
\hline \multirow{2}{*}{$\begin{array}{c}\text { hCG- } \\
\text { ovariectomy }\end{array}$} & \multirow{2}{*}{$\begin{array}{l}\text { Culture } \\
\text { with } \\
\text { labelled } \\
\text { precursor }\end{array}$} & \multirow{2}{*}{$\begin{array}{l}\text { Further } \\
\text { culture }\end{array}$} & \multirow{2}{*}{$\underset{\text { oviduct }}{\text { In }}$} & \multicolumn{2}{|c|}{$\begin{array}{l}\text { No. of } \\
\text { eggs }\end{array}$} & \multicolumn{4}{|c|}{ Stages of labelled eggs } \\
\hline & & & & Evaluated & Fertilized & Syngamy & $2-3$ cells & 4 cells & $6-8$ cells \\
\hline \multicolumn{10}{|l|}{$\left[{ }^{3} \mathrm{H}\right]$ Lysine } \\
\hline 8 & 3 & 24 & 16 & 18 & 8 & $8^{*}$ & & & \\
\hline 24 & 3 & 10 & 24 & 9 & 9 & $3 \dagger$ & $6+$ & & \\
\hline 24 & 3 & 10 & 48 & 14 & 12 & $1 \dagger$ & $3 \dagger$ & $8 \ddagger$ & \\
\hline \multicolumn{10}{|c|}{$\left[{ }^{3} \mathrm{H}\right]$ Methionine } \\
\hline 8 & 3 & 24 & 16 & 10 & 8 & $8^{*}$ & & & \\
\hline 24 & 3 & 10 & 48 & 6 & 6 & & $2^{*}$ & $4^{*}$ & \\
\hline \multicolumn{10}{|c|}{$\left[{ }^{3} \mathrm{H}\right]$ Tryptophan } \\
\hline 8 & 3 & 24 & 16 & 9 & 7 & $5^{*}$ & $2^{*}$ & & \\
\hline 24 & 3 & 10 & 48 & 11 & 7 & & & $2 *$ & $5^{*}$ \\
\hline
\end{tabular}

\section{Discussion}

The transformation of the mammalian sperm nucleus into a pronucleus in the egg cytoplasm is believed to be governed by factors provided during oocyte meiotic maturation (Thibault, Gérard \& Menezo, 1975). In the toad transformation is dependent on material released into the ooplasm during germinal vesicle breakdown (Skoblina; 1976; Katagiri \& Moriya, 1976). The integration of male chromatin into zygote metabolism probably first involves the loss of sperm nuclear protein(s) and then its substitution by proteins of oocyte origin (Das, Micou-Eastwood \& Alfert, 1975; Kopečný \& Pavlok, 1975a, b; Kunkle, Longo \& Magun, 1978; Marushige \& Marushige, 1978). The newly synthesized histone-type proteins, after $\left[{ }^{3} \mathrm{H}\right]$ arginine labelling, of mouse oocytes from metaphase II during fertilization in vitro are associated with all chromatin structures very soon after fertilization, concomitantly with the start of their transformation to pronuclei (Kopečný \& Pavlok, 1975b). However, in the present experiments, $\left[{ }^{3} \mathrm{H}\right]$ lysine-labelled proteins synthesized during meiotic maturation in rabbit and pig oocytes in vitro were retained in the ooplasm and accumulated only in fully grown pronuclei near or at syngamy. In pig zygotes there was no distinctive labelling of the nuclei in 4-cell stages. It seems probable that, unlike those of amphibians (Woodland \& Adamson, 1977), the cleaved eggs of mammals synthesize most of the histones required for nuclear replication. Further experiments are now in progress to confirm this supposition.

During meiotic maturation the non-histone proteins, as detected by tryptophan labelling, do not accumulate in the germinal vesicle of mouse (Wassarman \& Letourneau, 1976) and pig (J. Motlik \& V. Kopečný, unpublished observation) oocytes, but methionine labelled with ${ }^{35} \mathrm{~S}$ or ${ }^{3} \mathrm{H}$ was intensively accumulated in the germinal vesicle in pigs (Motlík et al., 1978; J. Motlík \& V. Kopečný, unpublished observation), and in Xenopus (Bonner, 1975; De Robertis et al., 1978).

Non-histone proteins newly synthesized after fertilization are concentrated in the pronuclei of frog eggs in amounts 1.2-7 times greater than in surrounding ooplasm (Di Berardino \& Hoffner, 1975; Hoffner \& Di Berardino, 1977). In the present experiments $\left[{ }^{3} \mathrm{H}\right]$ tryptophanlabelled proteins synthesized during the germinal vesicle stage were similarly accumulated in pronuclei of pig oocytes. Nuclei of the Rana pipiens blastula contained 5-10 times more radioactivity than did cytoplasm when oocytes were injected with $\left[{ }^{3} \mathrm{H}\right]$ leucine at the metaphase I 
stage (Ecker \& Smith, 1971). Pig oocytes labelled by $\left[{ }^{3} \mathrm{H}\right]$ methionine and $\left[{ }^{3} \mathrm{H}\right]$ tryptophan in metaphase I also displayed an intensive nuclear accumulation of grains, at least up to the 4- and 8-cell stages, respectively (see Pl. 1, Figs 7 and 8).

The patterns of polypeptide synthesis in cleaving rabbit embryos derived from oocytes matured in vitro and in vivo are identical (Van Blerkom \& McGaughey, 1978b), and therefore the proteins labelled during in-vitro culture in our experiments are probably not different from those synthesized in vivo. The changes in polypeptide synthesis observed in mature oocytes and embryos from fertilization to the 8-cell stage are characterized as a gradual disappearance of detectable amounts of oocyte-characteristic polypeptides. Some of the proteins synthesized during meiotic maturation, probably of non-histone nature, are preserved in the cytoplasm and selectively transported into the nuclei of embryos at least up to the 8-cell stage. Such nuclear proteins may include macromolecules with regulatory function of genomic transcription (Stein, Spelsberg \& Kleinsmith, 1974).

\section{References}

Bonner, W.M. (1975) Protein migration into nuclei. II. Frog oocyte nuclei accumulate a class of microinjected oocyte nuclear proteins and exclude a class of microinjected oocyte cytoplasmic proteins. J. Cell Biol. 64, 431- 437 .

Das, N.K., Micou-Eastwood, J. \& Alfert, M. (1975) Cytochemical studies on the protamine-type protein transition in sperm nuclei after fertilization and the early embryonic histones of Urechis caupo. Devl Biol. 43, 333-339.

De Robertis, E.M., Longthorne, R.F. \& Gurdon, J.B. (1978) Intracellular migration of nuclear proteins in Xenopus oocytes. Nature, Lond. 272, 254-256.

Di Berardino, M.A. \& Hoffner, N.J. (1975) Nucleo-cytoplasmic exchange of non-histone proteins in amphibian embryos. Expl Cell Res. 94, 235-252.

Ecker, R.E. \& Smith, L.D. (1971) The nature and fate of Rana pipiens proteins synthesized during maturation and early cleavage. Devl Biol. 24, 559-576.

Hoffner, N.J. \& Di Berardino, M.A. (1977) The acquisition of egg cytoplasmic non-histone proteins by nuclei during nuclear reprogramming. Expl Cell Res. 108, 421-427.

Katagiri, Ch. \& Moriya, M. (1976) Spermatozoan response to the toad egg matured after removal of germinal vesicle. Devl Biol. 50, 235-241.

Kopečný, V. \& Pavlok, A. (1975a) Autoradiographic study of mouse spermatozoan arginine-rich nuclear protein in fertilization. J. exp. Zool. 191, 85-96.

Kopečný, V. \& Pavlok, A. (1975b) Incorporation of arginine ${ }^{3} \mathrm{H}$ into chromatin of mouse eggs shortly after sperm penetration. Histochemistry 45, 341345.

Kunkle, M., Longo, F.J. \& Magun, B.E. (1978) Nuclear protein changes in the maternally and paternally derived chromatin at fertilization. J. exp. Zool. 203, 371-380.

Marushige, Y. \& Marushige, K. (1978) Dispersion of mammalian sperm chromatin during fertilization: an in vitro study. Biochim. Biophys. Acta 519, 1-22.

Motlík, J. \& Fulka, J. (1974a) Fertilization of pig follicular oocytes cultivated in vitro. J. Reprod. Fert. 36, 235-237.
Motlík, J. \& Fulka, J. (1974b) Fertilization and development in vivo of rabbit oocytes cultivated in vitro. $J$. Reprod. Fert. 40, 183-186.

Motlík, J., Kopečný, V. \& Pivko, J. (1978) The fate and role of macromolecules synthesized during mammalian oocyte meiotic maturation. I. Autoradiographic topography of newly synthesized RNA and proteins in the germinal vesicle of the pig and rabbit. Annls Biol. anim. Biochim. Biophys. 18, 735-746.

Schultz, R.M. \& Wassarman, P.M. (1977) Specific changes in the pattern of protein synthesis during meiotic maturation of mammalian oocytes in vitro. Proc. natn. Acad. Sci. U.S.A. 74, 538-541.

Skoblina, M.N. (1976) Role of karyoplasm in the emergence of capacity of egg cytoplasm to induce DNA synthesis in transplanted sperm nuclei. $J$. Embryol. exp. Morph. 36, 67-72.

Stein, G.S., Spelsberg, Th.C. \& Kleinsmith, L.J. (1974) Nonhistone chromosomal proteins and gene regulation. Science, N.Y. 183, 817-824.

Szöllösi, D. \& Hunter, R.H.F. (1973) Ultrastructural aspects of fertilization in the domestic pig: sperm penetration and pronucleus formation. J. Anat. 116, 181-206.

Thibault, C., Gérard, M. \& Menezo, Y. (1975) Preovulatory and ovulatory mechanism in oocyte maturation. J. Reprod. Fert. 45, 605-610.

Van Blerkom, J. \& McGaughey, R.W. (1978a) Molecular differentiation of the rabbit ovum. I. During oocyte maturation in vivo and in vitro. Devl Biol. 63, 139-150.

Van Blerkom, J. \& McGaughey, R.W. (1978b) Molecular differentiation of the rabbit ovum. II. During the preimplantation development of in vivo and in vitro matured oocytes. Devl Biol. 63, 151164.

Wassarman, P.M. \& Letourneau, G.E. (1976) Meiotic maturation of mouse oocytes in vitro: association of newly synthesized proteins with condensing chromosomes. J. Cell Sci. 30, 549-568.

Woodland, H.R. \& Adamson, E.D. (1977) The synthesis and storage of histones during the oogenesis of Xenopus laevis. Devl Biol. 57, 118-135. 